\title{
Sufijos Despectivos en Inga
}

STEPHEN H. LEVINSOHN

Instituto Lingüístico de Verano 
"Para ganar con la palabra, ! use palabras más largas y con menos respeto $i "$.

La mayoría de los Inga se encuentran en el valle de Sibundoy, intendencia del Putumayo, y hablan un idioma afín al quechua. En el valle de Sibundoy existen dos dialectos de inga, (1). El dialecto más amplio está concentrado alrededor de Santiago, y lo hablan unos tres mil ingas. El otro dialecto está concentrado alrededor de San Andrés, un pueblo a tres kilómetros de Santiago, y hay unos ochocientos cincuenta hablantes. Los de Santiago y los de San Andrés tienen tradiciones distintas respecto a sus orígenes, y los dialectos muestran las mismas distinciones. Por ejemplo, el sufijo "sujeto de la primera persona con el objeto personal de la segunda persona" se manifiesta con -sa- en el dialecto de Santiago y -sca- en el de San Andrés; Santiago: yucachisaquimi; San Andrés: yucachiscaquimi "Le daré a usted" (2).

Los Inga hablan de antipatía, de vez en cuando, entre los dos grupos, y hemos visto evidencia de ésta en peleas entre jóvenes de partidos opuestos, y también en los sucesos de los cuentos con una diversidad de palabras de pelea. Por ejemplo chapungapa "mezclar, pelear", llutangapa "pegar, pelear", macangapa "golpear", puñutiyangapa "tener puños, pegar". También hay palabras prestadas del español; por ejemplo pegangapa, de "pegar"; peleangapa, de "pelear".

Para esta antipatía hay un grupo de sufijos despectivos muy distintivos, por lo cual el inga es excepcional entre los idiomas quechuas. El oyente puede notar que los Inga usan una entonación casi siempre monótona cuando están charlando. Fuera de las expresiones de sorpresa, de imitación o para pedir caridad, la entonación es más o menos la misma. Dentro de ésta los sufijos despectivos se separan claramente, porque cuando una palabra tiene uno de estos sufijos el acento generalmente cae sobre la última sílaba. En ese caso, la silaba también es cerrada. Hay muy pocas raíces que se completan con una sílaba cerrada, y el acento generalmente cae sobre la penúltima sílaba.

Los sufijos se dividen en tres grupos:
(a) Despectivos directos
(b) De incredulidad

(1) Este material se recopiló durante viajes hechos entre junio de 1968 y febrero de 1970 , auspiciados por el Instituto Lingüistico de Verano de Colombia. Este artículo se publicó primero en inglés en "Anthropological Lingu istics", Vol. 12 No.6 de junio de 1970.

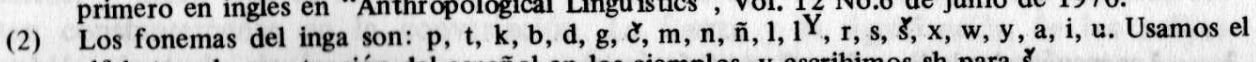
alfabeto y la acentuación del español en los ejemplos, $y$ escribimos sh para $\aleph^{\natural}$. 
(c) Un poco de desprecio y otros sentidos.

(a) Hay tres sufijos despectivos directos que se unen a cualquier clase de palabras Especialmente, cuando se unen al verbo, tienen referencia al sujeto o al objeto del verbo. Cuando se refieren al objeto del verbo, el sufijo objetivo ta también sigue inmediatamente después del sufijo despectivo.

\section{-Ash (3) Poco despectivo \\ -Aj Algo más despectivo \\ -Ans Muy despectivo}

Los Inga usan -ash de manera chistosa u orgullosa, pero también lo usan con enojo Un indígena Ínga dijo que -Aj manifiesta cariño. Tal vez está perdiendo algo de sv fuerza, porque los Inga lo usan más que los otros sufijos. Sin embargo, otros indígenas dicen que seguramente es despectivo. Todos los Inga concuerdan en que -Ans es sumamente despectivo.

Ejemplos (las palabras subrayadas en español son los focos de desprecio):

Sisay, nihuanash

Cuti sujpi derrumbosh tariri

Núcaca calpachiniajta cahuanga

Camaj lloronaj cangui.

Chipisi quedagrinchi, mamitáns

Nucanchi pegallajpinsta, huacangui.
"El me llamó ladrón".

"En otra parte también él encontró un derrumbe".

"Yo lo hice correr a ver"

"Usted es Ilorón".

"Allí vamos a quedar, bruja".

"Si nosotros solamente le pegáramos, usted lloraría."

(b) Si alguien usa el sufijo de incredulidad con foco sobre la misma persona a quien está hablando, entonces los Inga dicen que está buscando pelea. Se une estr sufijo a cualquier clase de palabras, menos al verbo.

- uj Incredulidad y desprecio a la persona objeto; también exige que la situación cambie.

Ejemplos:

Mana llashauj Imashauj pagá

"No pesa". (En realidad pesa mucho).

¡ Imashuj cantapuachu gálloca !

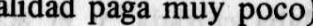

"¿Que cante más el gallo!"

(En realidad - ¡Que se calle el gallo! )

(c) Los otros dos sufijos se unen a cualquier clase de palabras. Especialmente cuando se unen al verbo siempre tienen referencia al sujeto.

-Ajim Simpático, a menudo sarcástico ("pobrecito").

-Ashim Chistoso.

$35^{3} 8$ Las mayúsculas indican formas morfofonémicas.
Ejemplos:

Nis payjimta, iscandijimta, sachucu apanga sitangapa.

Miticuysi callarinajimcuna.

Nuca huauquishimta, urmachí.

Nucashim chihora unguj carcani.

"Entonces los llevó a los dos para abandonarlos en el monte".

"Ellos empezaron a correr".

"El hizo caer a mi hermano". (como chiste).

"En ese tiempo yo estaba enfermo".

Analizamos 128 cuentos, dados por 33 hablantes y con un total de 5.121 cláusulas. Mostramos la distribución de sufijos despectivos en el Cuadro I.

\section{Cuadro I}

\begin{tabular}{|c|c|c|c|}
\hline & SUFIJO & Acontecimientos & Número de hablantes \\
\hline (a) & $\begin{array}{l}\text {-Ash } \\
\text {-Aj } \\
\text {-Ans } \\
\text { Total }\end{array}$ & $\begin{array}{r}18 \\
107 \\
26 \\
151\end{array}$ & $\begin{array}{r}2 \\
10 \\
7\end{array}$ \\
\hline (b) & $-u j$ & 3 & 1 \\
\hline (c) & $\begin{array}{l}\text {-Ajim } \\
\text {-Ashim } \\
\text { Total }\end{array}$ & $\begin{array}{r}62 \\
4 \\
66\end{array}$ & $\begin{array}{r}14 \\
2 \\
\end{array}$ \\
\hline & Total & 220 & 16 \\
\hline
\end{tabular}

Estos 220 sufijos se encuentran con un promedio de una vez en 23 cláusulas. Mostramos la distribución entre cuentos y hablantes en el Cuadro II

\section{Cuadro II}

\begin{tabular}{|l|c|c|c|c|}
\hline & $\begin{array}{c}\text { Los que usaron los } \\
\text { sufijos despectivos } \\
\text { (a) o (b) }\end{array}$ & $\begin{array}{c}\text { Los que usaron } \\
\text { solamente el } \\
\text { sufijo (c) }\end{array}$ & $\begin{array}{c}\text { Los que no } \\
\text { usaron sufijos } \\
\text { despectivos }\end{array}$ & Total \\
\hline Hablantes & 10 & 6 & 17 & 33 \\
Cuentos & 35 & 8 & 85 & 128 \\
\hline
\end{tabular}

En varios cuentos, encontramos sufijos despectivos con un promedio de uno en siete o menos cláusulas. En una conversación grabada en magnetófono, dos alumnos de una escuela usaron 44 sufijos despectivos en 321 cláusulas.

La actitud de los Inga frente a los sufijos despectivos nos parece que es la siguiente: Los miembros de varias familias (abuelos, padres y niños) generalmente se guardan de usarlos, y dicen que es mejor usar "las formas cortas". En cambio, otras familias los usan constantemente en la conversación. La fuerza y la significación de los sufijos también depende de la persona, especialmente - Aj. Por eso, nos parece que entre 
varias familias el usarlos es considerado como habla normal. En el grupo especialmente,-Ajim es la excepción. Lo usa una variedad más grande de hablantes expresa simpatía verdadera en varios contextos.

En conclusión, debemos preguntarnos por qué existe tal manera de difamar al vecin Tal vez el sistema complicado de sufijos en quechua permitió con facilidad otro orden sufijos para expresar una necesidad de las circunstancias y la cultura de los Inga. 0 posibilidad interesante es que el camsá, el idioma vecino de Sibundoy, a unos kilómetros de santiago, ha sido el catalizador para producir estos sufijos. El fonema ocurre en Inga solamente en préstamos del camsá, y en los sufijos despectivos-Ash, Ashim. El fonema $\mathrm{x}$ es raro en inga, fuera de los sufijos $-\mathrm{Aj},-\mathrm{uj}$, Ajim, pero tanto como $\mathrm{x}$ son fonemas muy comunes en el camsá.

Los Inga aprenden pocas frases y palabras del camsá, pues dicen que el cams "muy trabajoso" y "feo", y le dieron el nombre cuchi "marrano" al idioma. prominencia de los sonidos s y x en los sufijos despectivos tal vez sea el resultado de imiti a los indigenas de Sibundoy de una manera despectiva.

\section{BIBLIOGRAFIA}

Caudmont, J. "Los fonemas del Inga" Revista Colombiana de Antropologia, Bogotá I-i pp. 359-389, 1953

Castellvi, M.de "Advertencias sobre la Publicación de datos del Ingano" Boletín de Estudios Históricos. Pasto VI pp.182-192,1935.

Levinsohn, S.H.The Inga Language (Mouton y Cía, La Haya, en prensa), 